\title{
IDDAH OF WOMEN WHO HAD ABORTUS IN THE BOOK OF MUGHNI AL-MUHTAJ AND MUKHTASHAR KHALIL IN PERSPECTIVE OF MAQASID SHARI'AH
}

\author{
Wika Wulandari \\ Universitas Islam Negeri Sumatera Utara \\ Jl. Willem Iskandar Pasar V Medan Estate \\ Email: wikawulandari028@gmail.com
}

\begin{abstract}
Iddah is a period of waiting for a woman not to carry out a marriage after the death or divorce of her husband until the time limit determined by syara: As for the iddah period for a woman who is pregnant until she gives birth. However, the problem that arises in this life is what if the woman has an abortion. In this matter, there is a difference of opinion in the books of Mughni al-Muhtaj and Mukhtashar Khalil about the end of the iddah period of a woman who has an abortion. This research aims to find out how the opinions of the two books about iddah women who experience abortion and what causes differences of opinion, and which opinion is chosen. This research is a type of library research, which is descriptive with qualitative analysis, and the primary data source used is the book of Mughni al-Muhtaj and Mukhtashar Khalil. This study indicates that the difference in opinion is due to differences in the book's writers in interpreting the word al-haml and the rules of ushul fiqih used. Moreover, from the two opinions, Muhammad Khatib asy-Syarbaini in the book Mughni al-Mubtaj which was chosen because it followed the wisdom of determining iddah.
\end{abstract}

Keywords: Abortion; Iddah; Mughni al-Muhtaj; Mukhtashar Khalil; Pregnant

\begin{abstract}
Abstrak: Iddah merupakan masa menunggu bagi wanita untuk tidak melaksanakan pernikahan setelah ditinggal mati atau diceraikan oleh suaminya, sampai batas waktu yang telah ditentukan oleh syara'. Masa iddah bagi wanita yang sedang hamil sampai ia melahirkan. Namun, permasalahan muncul jika wanita tersebut mengalami abortus. Dalam masalah ini, terjadi perbedaan pendapat dalam kitab Mughni al-Muhtaj dan Mukhtashar Khalil tentang berakhirnya masa iddah seorang wanita yang mengalami abortus. Tujuan dari penelitian ini ialah untuk mengetahui bagaimana pendapat dari kedua kitab tersebut tentang iddah wanita yang mengalami abortus, apa yang menyebabkan terjadinya perbedaan pendapat, serta pendapat manakah yang terpilih. Penelitian ini merupakan penelitian kepustakaan, bersifat deskriptif dengan analisis kualitatif. Sumber data primer adalah kitab Mughni al-Muhtaj dan Mukhtashar Khalil. Hasilnya menunjukkan bahwa perbedaan pendapat tersebut disebabkan perbedaan penulis kitab dalam memaknai kata al-haml dan kaidah Ushul Figh yang digunakan. Dan dari kedua pendapat tersebut, pendapat Muhammad Khatib al-Syarbaini dalam kitab Mughni al-Muhtaj lebih kuat dan terpilih karena sesuai dengan hikmah disyari'atkannya iddah dan mengandung lebih banyak mashlahah.
\end{abstract}

Kata kunci: Abortus; Iddah; Mughni al-Muhtaj; Mukhtashar Khalil; Hamil 


\section{Introduction}

The main hope of every human being who will build a household is creating a sakinah, mawaddah, and warahma family. Households that are always decorated with joy and full of smiles, joys, and sorrows are faced together to increase love and gain the pleasure of Allah.

However, sometimes the reality is not as expected. Problems in the household may happen, even sometimes these problems continue without finding a bright spot as a proper solution. Such a situation makes a husband and wife feel uncomfortable so that family harmony can no longer be felt. Even mediation cannot reconcile the two parties until the divorce becomes the end of problemsolving.

After a divorce, a woman is obliged to undergo a period of iddah. Etymologically, iddah is taken from the word adad in the Al-Munawwir Dictionary, meaning count, number. ${ }^{1}$ In terminology, according to alShan'any, that is the name for a time when a woman waits for the opportunity to remarry because of the death of her husband or divorce from her husband. ${ }^{2}$

The period of $i d d a h$ of every woman depends on the circumstances or conditions when she is divorced or abandoned by her husband. The iddah of a woman whose husband divorces is three times quru'for those who have had husband and wife relations. However, a woman who has not had a husband and wife relationship does not have an obligation to perform iddah. As for the woman whose husband died, her iddah period is four months and ten days, whether for women who are married or not. The iddah of a pregnant woman is until she gives birth.

${ }^{1}$ Ahmad Warson Al-Munawwir, Kamus Al-Munawwir Arab-Indonesia Terlengkap, (Yogyakarta: Pustaka Progressif, 1997) p. 904.

2 Al-San'any, Subul al-Salam, Juz III (Kairo: Syirkah Maktabah Mustafa al-Babi al-Halabi, 1960) p.196.
There is no difference of opinion among scholars regarding the period of iddah of a pregnant woman until she gives birth. Namun, yang jadi masalah adalah ketika wanita tersebut mengalami abortus. However, the problem is when the woman has an abortion. In response to this, al-Syarbaini, in his book Mughni alMubtaj said that the woman's iddah had not ended if what came out was 'alaqah, and the woman was acquitted of being pregnant. However, if what comes out is mudghah, then the woman's iddah ends. In contrast to Shaykh Khalil Bin Ishaq al-Maliki, who states in the book Mukhtashar Khalil that the iddah of a woman who experiences an abortion ends even though what comes out is only 'alaqah, because it has shown that she will become a mother.

From the differences of opinion above, three questions arise: First, what is the opinion about the iddah of women who experience abortion in the books of Mughni al-Muhtaj and Mukhtasar Khalil? Second, what causes differences of opinion in the books of Mughni al-Muhtaj and Mukhtasar Khalil regarding the iddah of women who experience abortions? Therefore, research is needed that will answer these three questions.

The purpose of this study is to provide answers to the three questions above. Although this research studies classical ulama's books, it does not close the relevance to the present. Because with the development of science and technology, scientists in the medical field have made the classification of abortion itself. Thus, it can be seen that the two different opinions belong to which classification.

Abortion itself is medically the cessation of pregnancy with the death and expulsion of the fetus at the age of fewer than 20 weeks with a fetal weight of fewer than 500 grams, i.e. before the fetus can live outside the womb independently. ${ }^{3}$

3 Yuli Susanti, "Perlindungan Hukum Bagi Pelaku Tindak Pidana Aborsi (Abortus provocatus) Korban 
Abortion is also divided into several types, namely: complete abortion, incomplete abortion, abortion insipient, abortion imminent, missed abortion, and habitual abortion.

\section{Iddah Paradigm}

Etymologically, the word iddah comes from Arabic, عدة which means count, while iddah is a masdar form of fi'il madhi 2 which means count, while iddah is a masdar form of fi'il which means counting. ${ }^{4}$ As for Sayid Sabiq, the term iddah is pronounced as follows:

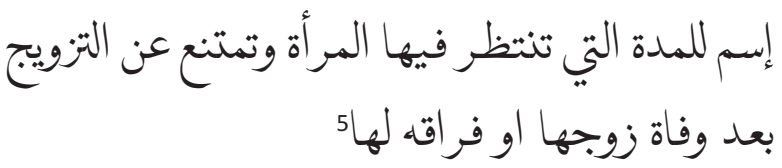

"iddah is the name for a period, where a woman waits and prevents herself from marrying after her husband dies or after divorce."

Besides Sayyid Sabiq, Muhammad al-Zahri alGhamrawi gave the term iddah with a different editor. According to him, Iddah is a syara' term, which is a period of waiting for a woman due to divorce to clean up the residue caused by a husband and wife relationship or the like. ${ }^{6}$

From the various definitions above, it can be seen that there are differences between the scholars in defining iddah. However, if the substance is understood, then each definition presented has something in common, namely, iddah is a grace period for a woman not to carry out a marriage after being left dead or divorced by her husband until the time limit determined syara'. This is a form of condolence for self-reflection or cleansing of a woman's womb.

Perkosaan," FH.UNISBA: Jurnal Ilmu Hukum, 16, 2 (September 2010-Februari 2013): p. 10.

${ }^{4}$ Mahmud Yunus, Kamus Arab-Indonesia, (Jakarta: Hindakarya Agung, 1989), p. 225.

5 Sayyid Sabiq, Fiqh Sunah, juz II, (Beirut: Dar alFikr, 1983), p. 325.

${ }^{6}$ Muhammad al-Zahri al-Ghamrawi, Al-Siraj al-Wahaj, (Bairut, Libanon: Dar al-Kutub al-Alamiyah, t.th), p. 435.
The period of iddah that a woman must live as a result of divorce or because her husband has left her is not the same, depending on how the woman was when she died or was divorced. The provisions are based on the arguments contained in the Qur'an and hadith. A woman's iddah, in general, is three times quru'. Nevertheless, for a woman whose husband has died, her iddah period is four months and ten days, whether she has had marital relations or not. As Allah says:

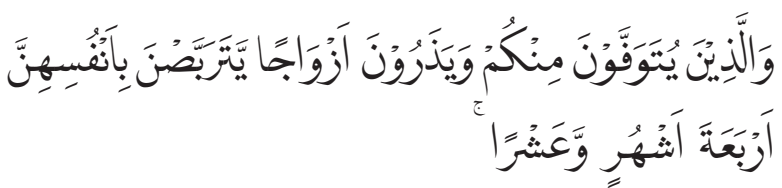

"Those who die among you leaving their wives (let the wives) defer themselves (iddah) for four months and ten days." (Q.S. Al-Baqarah [2]: 234)

As for the woman whose husband has divorced but has not had marital relations, the woman is not obliged to undergo the iddah period as Allah says:

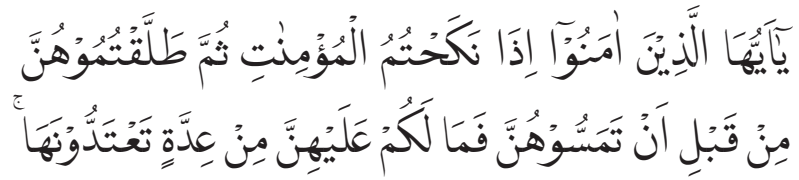
"O you who believe, if you marry believing women, then you divorce them before you interfere, then it is not obligatory for them to make an iddah for you which you ask to complete." (Q.S. Al-Ahdzab [33]: 49)

While the period of iddah for a woman who is no longer menstruating (monopouse) is three months, and the iddah of a woman who is pregnant until she gives birth. Allah says in the Qur'an:

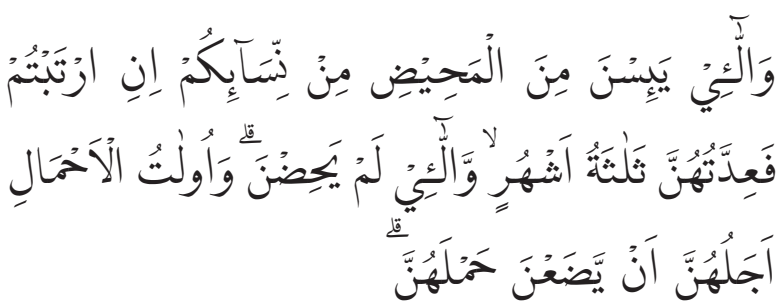

"And women who do not menstruate again (menopause) among your women if you have 
doubts (about the period of iddah), then their iddah period is three months; and so (also) women who do not menstruate. Moreover, pregnant women, their iddah is until they give birth to their wombs". (Q.S. Al-Thalaq [65]: 4)

In marriage law, iddah is known as waiting time. The provisions for waiting time in the Marriage Law in chapter VII article 39 states that: If the marriage breaks up due to death, the waiting time is 130 days, if the marriage breaks up due to divorce and the woman is still menstruating, the waiting time is three times sacred with at least ninety days, if the marriage breaks up while the woman is pregnant, then the waiting time is until she gives birth, and there is no waiting period for women who have not previously had a husband-wife relationship with her ex-husband. ${ }^{7}$

\section{Abortion Concept}

The word abortion comes from the English language, namely abortion which in the Indonesian English dictionary is translated as abortion. ${ }^{8}$ In Arabic terms, abortion is known as the word al-ijhad (الاجهاض) or commonly known as isqat al-haml (استاط الحمل) the origin of the word is ستط-يستط-سقطا- which means to drop, to prevent.' As for al-Gazali termed abortion with the word (الاجهاض) as written in his book of Ihya Ulum al-Din ${ }^{10}$ وليس هو كاجهاض which means it is not like abortion.

Furthermore, in terminology, Holmer said abortion is the termination of pregnancy before the 16th week where placentation has not been completed. ${ }^{11}$ Meanwhile, according to

${ }^{7}$ Marriage Law, full edition, (Bandung: Fokusmedia, 2005 ), p. 45-46.

8 Echols, dan Hassan Shaddily, Kamus Inggris Indonesia, (Gramedia:Jakarta, 1992), p. 2.

${ }^{9}$ Muhammad Idris 'Abd al-Rauf al-Barbawi, Qamus Idris al-Marbawi, Juz I, (Jakarta: Karya Insa, t.th), p. 292.

${ }_{10}$ Al-Gazali, Ihya Ulum al-Din,(Kairo: Mu'assasah, 1967), p. 53.

${ }^{11}$ Rustam Mochtar, Sinopsis Obsetetri, (Jakarta: EGC, 1998), p. 209.
Muhammad Said Rahman al-Buti, abortion is an act of separating the fetus from its mother before the birth is complete according to custom, be it the efforts of the pregnant person itself or the efforts of others, either by hitting the pregnant person's stomach, by surprising, giving medicine. Or in some other way ${ }^{12}$.

Based on the definitions above, it can be concluded that abortion is a state of the expulsion of the products of conception from the mother's womb before the fetus is $20-28$ weeks old or prematurely.

With the advancement of technology in the medical field, abortion is divided into two. First, spontaneous abortion is an abortion that occurs by itself, unintentionally or not preceded by mechanical or medical factors, solely caused by natural factors. In this case, spontaneous abortion is further divided into six types: Imminent abortion, which is vaginal bleeding in pregnancy less than 20 weeks, without any signs of increased cervical dilatation. An abortion insipient is an event of uterine bleeding in pregnancy before 20 weeks with increased uterine cervical dilatation, but the products of conception are still in the uterus. Incomplete abortion is the expulsion of part of the products of conception in pregnancy before 20 weeks with some remaining in the uterus. Complete abortion is the expulsion of all products of conception in pregnancy before 20 weeks. Missed abortion is defined as the retention of products of conception that have died in utero for several weeks. Recurrent abortion is defined according to various criteria of number and sequence, but perhaps the most widely accepted definition is three or more consecutive spontaneous abortions. A woman suffers from recurrent/habitual abortion if she

${ }^{12}$ Muhammad Said Rahman al-Buti, Tahdid al-Nasl, (Damsyq: Maktabah al-Farabi, 2011), p.187 dikutip oleh Aripin Marpaung, Diktat Fikih Kontemporer, (Fakultas Syari'ah dan Hukum, Institut Agama Islam Negeri Sumatera Utara, Medan, 2014), p. 66. 
has had three or more consecutive abortions. ${ }^{13}$

Second, abortion provocateurs, which is intentional abortion either by using drugs or tools. This abortion is also divided into two: Abortus provocateurs medicinalis, namely abortion carried out with medical indications. Furthermore, Abortus provocateurs criminalis, namely abortion that occurs because of actions that are not legal or not based on medical indications, and in general, it is said to be an early birth before the baby in time can live alone outside the womb. In general, the fetus that came out was no longer lifeless. ${ }^{14}$

According to the majority of fuqaha, it is unlawful to have an abortion for a fetus that is 120 days old. While the age before 120 days occurs khilafiyah. Some argue that it is permissible, makruh, and haram. According to Imam al-Ramli from the Imam Shafi'i group, it is illegal to have an abortion for a fetus that is 120 days old. Because it is estimated that the fetus is alive, for those who do, then the punishment is ghurrah, ${ }^{15}$ diyat which must be fulfilled by the person who commits the killing of the fetus, in the form of paying a male or female slave to the family of the fetus or paying kafarat equal to one-twentieth of the usual diyat, namely five camels. Meanwhile, abortion before 120 days is legal.

Ibn Hazm also argues that killing a fetus after the spirit has been breathed and its age

\footnotetext{
${ }^{13}$ Julita Anriani Lubis, "Perbedaan Kadar Glutation Peroksidase Pada Abortus Imminens Dan Hamill Normal Trimester I Di RSUP. H. Adam Malik, Dan RS. Swasta Medan”, Tesis, Universitas Sumatera Utara, Medan, 2014), p. 11

${ }^{14}$ Sri Setyowati, Masalah Abortus Kriminalis Di Indonesia Dan Hubungannya DenganKeluarga Berencana Ditinjau Dari Kitab Undang-Undang Hukum Pidana,(Jakarta: t.p., 2002), p. 99.

15 Syihabuddin al-Ramli, Nihayat al-Mukhtaj, Syarh alMinhaj fì al-Fiqh' ala Madzhab al-lmam Syafi'i, jilid VII, (al-Halabi, 1357 H), p. 416 dikutip oleh Dewani Romli, "Aborsi Dalam Perspektif Hukum Positif Dan Hukum Islam(Suatu Kajian Komparatif), "Al-'Adalah, Vol. X, No. 2, Juli 2011, p. 160.
}

reaches 120 days is considered a crime of intentional murder and is punishable by qishas unless the victim is forgiven. This action is obligatory to ghurrah and is not obliged to pay kafarat because it is considered an intentional murder. ${ }^{16}$ Ibn Qudamah argues that if it turns out that the fetus dies as a result of a beating on the mother's abdomen, then the perpetrator is given a reward in the form of kafarat, in addition to diyat and ghurrah, namely freeing a believing slave. If he is unable to do so, then he must fast for two consecutive months. It is obligatory upon him whether the fetus is alive or dead.

As for the law in Indonesia, the issue of abortion that is regulated is only about abortion provocatus. In the Criminal Code (KUHP), the act of intentional abortion (abortus provocatus) is regulated in the second book of Chapter XIV concerning Moral Crimes, especially Article 229 paragraph 1, which reads, "Whoever intentionally treats a woman or orders her to be treated, by being notified or an expectation is raised that because of this treatment, her pregnancy can be aborted, she is threatened with a maximum imprisonment of four years or a maximum fine of three thousand rupiahs, is punishable by a maximum imprisonment of four years.

\section{Iddah of Aborted Women in the Book of Mughni Al-Muhtaj and Mukhtashar Khalil}

1. Iddah of Aborted Women in the Book of Mughni Al-Muhtaj

As the author has explained in the previous discussion, the iddah of a woman who is pregnant is until she gives birth as the word of God:

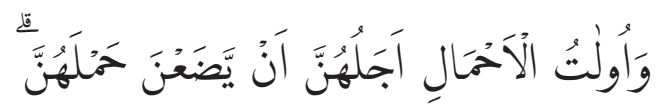

${ }^{16}$ Ibn Hazm, al-Muhalla, jilid XI, (Kairo: al-Muniria, 1352 H), p. 234 dikutip oleh Dewani Romli, "Aborsi Dalam Perspektif Hukum Positif Dan Hukum Islam(Suatu Kajian Komparatif)," Al-'Adalah: Vol. X, No. 2 (Juli 2011): p. 160. 
"...And the women who are pregnant, the time of their iddah is until they give birth to their wombs..." (Q.S. Al-Thalaq [65]: 4)

The above verse has clearly explained that a pregnant woman's iddah is until she gives birth to her womb. In this case, all scholars agree, and no one denies it. However, there is a problem when a pregnant woman is sentenced to talaq by her husband, and not long after that, the woman has aborted in the womb. Is it with the abortus that the woman's iddah is gone? This is where the scholars differ in their responses.

In the book of Mughni al-Mubtaj, it is written that the iddah of women who undergo abortion will only die if the one who comes out in the form of a lump of meat (mudhgah). Moreover, do not fall in the iddah period if all that comes out is only a lump of blood (alaqah). As written in the book of Mughni al-Muhtaj:

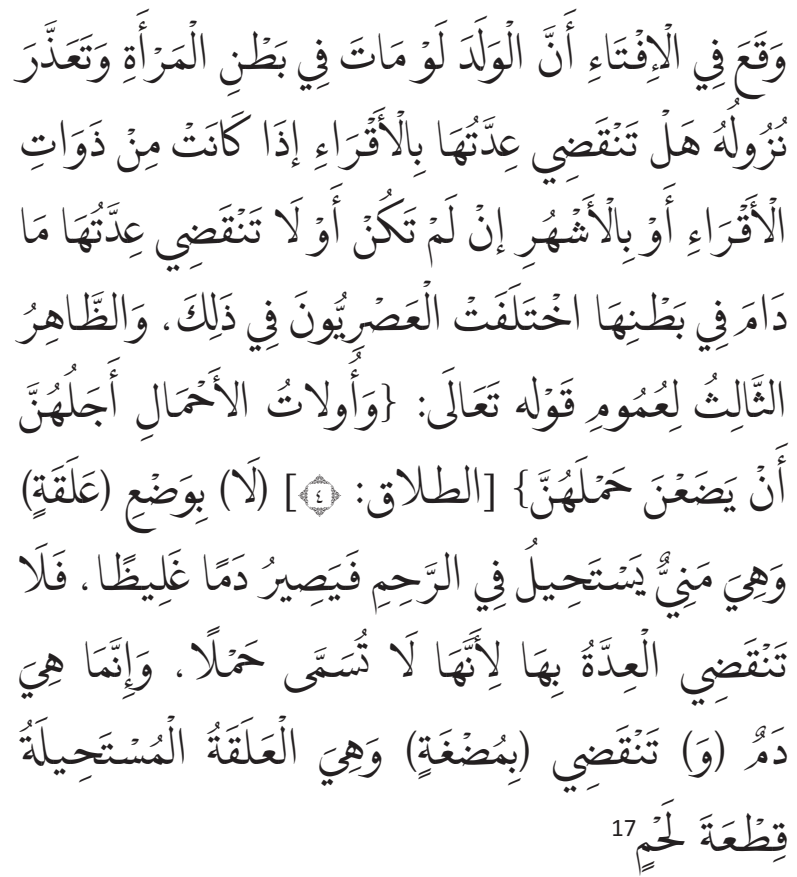

"Stipulated in some fatwas that if there is a child who dies in the stomach of the woman and the woman experiences pain in the death of the child, is the sacredness of the woman's uterus has been completed along with the bleeding that has aged or with several months if it is still not

${ }^{17}$ Muhammad Khatib Asy-Syarbini, Mughni Al-Muhtaj, Juz IV( Jakarta: Dar Al-Ammiyah, 2018 M ), p. 349. clean the uterus or iddahnya not finished if the child who miscarried is still in the womb? There is a difference of opinion among the scholars" Asriyun on the matter, and according to qoul dhohir is the third as in the word of Allah: "And the women who are pregnant when their iddah is until they give birth to the womb" (AlThalaq: 4). Not for removing alaqah and what is meant by alaqoh is semen that sticks in a woman's womb and turns into a lump of blood, the woman has not punished iddah for him, For if it is only 'alaqah (from the pregnant woman), it is not called pregnant, and in fact, it is still a blood clot. Furthermore, punished finished (iddah) with the release of mudhghoh that is a lump of blood that turns into a lump of meat."

In detail explained in the book of Mughni Al-Muhtaj that the iddah of women who have abortus that is still in the form of a lump of blood (alaqah) does not end because women in these circumstances can not be said to be pregnant women (لاتسى حملا). Moreover, it also explained that the period of iddah of the woman is the same as the time of the woman's iddah in general.

According to the author's opinion, what is conveyed in the book of Mughni Al-Muhtaj, which states that the iddah of a woman who undergoes abortion in the form of a lump of blood (alaqah) has not ended, is a form of how she understands the Qur'anic verse at-Thalaq verse 4, namely in the word ان يضعن حملن Furthermore, this is part of the prudence of Muhammad Khatib al-Syarbaini in interpreting the Qur'anic verse. As for his prudence in interpreting this verse is the influence of the knowledge he learned from Imam al-Shafi'i, who is his teacher in studying the science of fiqh and in istinbath (excavation and discovery) of the law on a case.

ان يضعن The author of the book argues that is the proper interpretation of childbirth. Childbirth is when the present in a woman's stomach is already visible as a human being. 
حملهن According to al-Syarbaini, the word is interpreted as being genuinely pregnant. The meaning is that the fetus's condition is no longer a lump of blood ('alaqah). So that the woman who has abortus and is still in this phase then does not immediately fall during her iddah, and she must replace it with an ordinary woman's iddah.

According to the author, al-Syarbaini's attitude makes the Qur'anic verse the only proposition to maintain validation of his opinion to avoid the placement of the law that is contrary to the law of syara'. In addition, al-Syarbaini also uses the fiqh rule as a reinforcement of his opinion. The figh rule he uses is الاصل براء الزمة. (The origin of something is free from dependents).

If it is associated with the case of pregnant الاصل براء women who have abortus with the rule الزمة it means that basically, a woman's uterus is free from dependents or uterine voids. So if there is an abortus at the gestational age of fewer than 20 weeks and still in the form of a lump of blood ('alaqaah), then it can not be said a pregnant woman because it is free from pregnancy.

In addition, if analyzed with the current situation, then technology in the field of medicine is undoubtedly sophisticated to detect a woman's pregnancy. As for if it is associated with the classification of abortus, then the abortus that can abort the iddah time of a woman in the book of Mughni al-Muhtaj is incompatible abortus above four weeks.

\section{Iddah of Abortus Women in the Book of Mukhtasar Khalil}

In the book of Mukhtasar Khalil, the iddah of the woman who had abortus has died even though the one that came out is still in the form of a lump of blood ('alaqah). This can be seen in the following statement.:

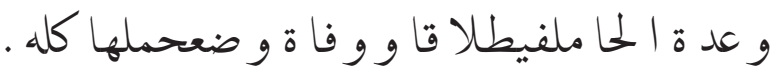

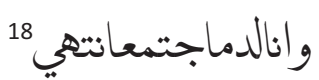

"And the iddah of a pregnant woman who is rejected (her husband) or left for dead until she gives birth, even though (in the form of) blood that clots out (the iddah period)."

From the above, it seems clear that a woman whom her husband rejected was pregnant, and then she had abortus, then had died during the woman's iddah even though that came out only in the form of a lump of blood. As for the above opinions as to the word of Allah in the Qur'an:

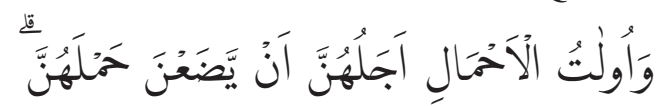
"...And the women who are pregnant, the time of their iddah is until they give birth to their wombs..." (Q.S. Al-Thalaq [65]: 4)

According to the author of Mukhtasar Khalil sheikh Khalil bin Ishaq al-Maliki, the pronunciation of الحمل covers all types of pregnancy even in the form of a lump of blood ('alaqah). Pregnancy in the form of a lump of blood has shown that the woman will become a mother. (تكون بها امرولد).

According to Ibn Qasim, the characteristics of blood in question are as follows:

و علامة هذ الداه ان يصب عليه الماء فلا يذوب19 "And the characteristic of this blood when watered with water then it does not melt."

In addition, Ibn Qasim al-Kharasyi also commented on the iddah period of women who had abortus contained in the book of Mukhtasar Khalil, he said.:

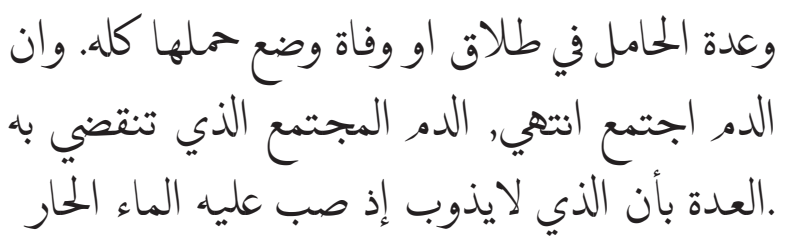

${ }_{18}$ Khalil Bin Ishaq al-Maliki, Mukhtasar Khalil, cet ke-2 ( Beirut: Dar al-Madaru al-Islam, 2004), p. 137.

19 Khalil Bin Ishaq al-Jundi al-Maliki, al-Taudih $f i$ Syarhi Mukhtashar al-Far'iyi li Ibni Hajib, (Mesir: Dar Najibuih, 2008), p. 24. 
"And the iddah of a pregnant woman who is rejected (her husband) or left for dead until she gives birth. Even though (in the form) of blood that clots out (the iddah period). The lump of blood that ends the iddah is the one that does not melt when watered hot water."

From the above exposure, it can be taken the essence that according to Sheikh Khalil bin Ishaq as the author of the book Mukhtasar Khalil, the iddah of a woman who had abortus has ended even though the one that came out is only a lump of blood. Because according to him, a lump of blood is a sign that a woman will become a mother. According to Ibn Qasim, the lump of blood in question is a lump of blood that does not melt when watered. Then alKharasy explained again that a lump of blood does not melt when watered with hot water.

However, the opinion that the author has expressed above is refuted by Asyhab, he said:

$$
\text { لاتحل بالده المطلقة و لاتكون به الامة ام ولد }
$$

"A pregnant woman is not lawful to marry if she only bleeds, and she is not also referred to as a mother-to-be.."

Despite the differences of opinion above, if viewed in the context of the current situation, when medical technology is increasingly sophisticated to see the unseen before, then the opinions listed in the book of Mukhtasar Khalil are included in the classification of abortus imminent.

\section{Causes of Differences in Opinion and Analysis of Maqasid Shari'ah}

From the above explanation, it can be known that the differences of opinion contained in the book of Mughni al-Muhtaj and Mukhasar Khalil are not based on differences

${ }^{20}$ Abu Muhammad Al-Kharasyi, Syarah Mukhtashar AlKhalil, (Mesir: Al-Kubra Al-Amiri, 1317 H), Juz IV, p.143.

${ }^{21}$ Khalil bin Ishaq al-Jundi al-Maliki, al-Taudih $f i$ Syarhi..., p. 24. in propositions, but because of differences between the two authors in understanding the word ان يضعن حملهن.

In the book of Mughni al-Muhtaj, it is said that the woman who had abortus is still in the form of blood, then the iddah period does not fall because the woman is not said to be a pregnant woman. This opinion is the caution of the author of the book in interpreting the verses of the Qur'an. As in the book of Mukhasar Khalil, the time of iddah, a woman who had abortus, although still in the form of a lump of blood, it has aborted the time of her iddah. This is because according to the author of the book Mukhasar Khalil, the word الحمل includes all types of pregnancy, be it a lump of blood (alaqah) or a lump of meat (mudhghah).

If the two opinions are classified, then the opinion in the book of Mughni al-Muhtaj is included in the classification of incomplete abortus above four weeks. This abortus is characterized by the discharge of dead fetal tissue from the womb and causes continuous bleeding. A woman who has this abortion, then there is no chance that her pregnancy will survive.

While the opinion in the book of Mukhtasar Khalil is included in the classification of abortus imminent, it is a condition of severe bleeding that allows a woman to have an abortus and lose her womb. This condition is characterized by brownish spots that are usually accompanied by blood clots from the vagina. However, this abortion can still be treated, or in other words, a woman who has abortus imminent can still try to save her womb by resting completely.

From the above explanation, it can be said that the opinion in the book of Mughni alMubtaj is stronger than the opinion in the book of Mukhtasar Khalil because the opinion in the book of Mughni al-Muhtaj is commensurate with the purpose in his shari'a iddah, which is to know the emptiness of the womb of a woman. While the opinion in the book of Mukhtasar Khalil still allows the woman to 
be pregnant. So the chosen opinion is the opinion of Muhammad Khatib Al-Syarbaini in the book of Mughni al-Muhtaj. This is because his opinion is following the purpose of iddah. According to Totok Jumantoro, the essence of maqasid shariah is for the benefit of man. Then Muhammad Syrukri Albani added that the benefits could be well realized if the five main elements can be realized and maintained: religion, soul, descendants, reason, and treasure. ${ }^{22}$

So in this matter, the opinion of Muhammad Khatib al-Syarbaini in the book of Mughni alMuhtaj has fulfilled the element of preserving offspring because his opinion clearly shows the empty uterus of a woman. Because if the woman who has an abortion is above four weeks, it is unlikely that her pregnancy can be saved. Even the remains of the fetus that has been killed must be removed because if not removed, it will harm the mother physically.

While the opinion in the book of Mukhtashar Khalil is included in the classification of abortus imminent because the baby in the womb of the woman who experienced it can still survive, and if he gets married, it will cause uncertainty about the child he was born with. If the child he was born with and who married him is his stepfather and considers it his biological child, then the child's marriage is not valid because the stepfather is not his guardian. Moreover, when he has a husband and wife relationship, he actually commits adultery due to the invalidity of the marriage.

\section{Conclusion}

Iddah cover is a grace period for a woman not to carry out a marriage after being left dead or divorced by her husband until the deadline specified by the syara'. An abortus is a state of discharge resulting from conception from the

${ }^{22}$ Muhammad Syukri Albani Nasution, Filsafat Hukum Islam, (Jakarta: Rajawali Pers, 2014), cet-2, p. 105. mother's womb before the fetus is $20-28$ weeks old or premature; in the book of Mughni alMuhtaj, iddah women who undergo abortion end if the one that comes out in the form of mudghah. However, if the exit is still in the form of alaqah, it cannot end the period of his iddah, and the woman's iddah must be replaced with a woman's iddah in general, which is three times quru'. This is because women who experience abortion after the alaqah phase are not said to be pregnant women. While in the book of Mukhtashar Khalil, iddah, a pregnant woman who had abortus, has ended even though it is still in the alaqah phase. Moreover, the lump of blood in question is the blood that does not melt when watered with water.

The proposition used in the books of Mughni al-Muhtaj and Mukhatasar Khalil to determine the time of iddah of women who had abortus is Q.S at-Thalaq verse 4. The difference of opinion contained in the book of Mughni al-Muhtaj and Mukhasar Khalil is not based on differences in arguments, but because of the differences between the two authors in understanding the word ان يضعن حملهن.

In this regard, the opinion in the book of Mughni al-Muhtaj is more chosen than the opinion in the book of Mukhtasar Khalil because the opinion in the book of Mughni al-Muhtaj is commensurate with the purpose in his shari'a iddah, which is to know the emptiness of the womb of a woman. While the opinion in the book of Mukhtasar Khalil still allows the woman to be pregnant.

\section{References}

Amna, Lukman. Aborsi Dan Hak Atas Pelayanan Kesehatan, http//:www.lbh-apik.or.id/fact-32. htm, (28 April 2020).

Barbawi, Muhammad Idris 'Abd al-Rauf al-. Qamus Idris al-Marbawi, Juz I, Indonesia: Karya Insa, t.th.

Buti, Muhammad Said Ramadan al-. Tahdid amNasl, Damsyq: Maktabah al-Farabi, 2011. 
Fatmawati. "Aborsi Dalam Perspektif Hukum Islam", Al-Maiyyah, Vol. 9 No. 1, Januari Juni 2016

Ghamrawi, Muhammad al-Zahri al-. Al-Siraj al-Wahaj, Beirut, Libanon: Dar al-Kutub al-Alamiyah, t.th.

Ghazali, Muhammad ibn Muhammad al-. Ihya 'Ulum al-Din,Kairo: Mu’assasah, 1967.

Hakim Nainggolan, Lukman. "Aspek Hukum Terhadap Abortus Provocatus Dalam Perundangundangan di Indonesia”, Jurnal Equality, Vol.11, No. 2, Agustus 2006.

Hazm, Ibn.al-Muhalla, jilid XI, Kairo: al-Muniria, $1352 \mathrm{H}$.

Jumiati. "Faktor-Factor Yang Berhubungan Dengan Abortus Di RSU Mutia Sari Duri Periode 2017", Jurnal Bidan Komunitas, Vol. II No.1 2017.

Karyssa Rompies, Jemmimah. https//www. popmama.com/pegnancy/second-trimester/ jemina/abortus-immines-penyebabkeguguran-saat-hamil, ( 6 Juni 2020).

Kharasyi, Abu Muhammad al-. Syarah Mukhtashar Al-Khalil, Mesir: Al-Kubra AlAmiri, 1317 H., Juz IV.

Kusmidi, Hendri. "Reaktualisasi Konsep Iddah Dalam Pernikahan", Jurnal Ilmiah Mizani, Vol. 4, No. 1 (2017).

Lailatul Musafaah, Nur. "Interprestasi Ayat Iddah Bagi wanita Hamil, Menopause, Amenorea, Dan Hamil Dengan Pendekatan Medis", AlDaulah, Vol. 8 No. 1, April 2018

Lubis, Anriani Julita. "Perbedaan Kadar Glutation Peroksidase Pada Abortus Imminens Dan Hamil Normal Trimester I Di Rsup. H. Adam Malik, Dan Rs. Swasta Medan", Tesis, Universitas Sumatera Utara Medan, 2014.

Maliki, Khalil bin Ishaq al-. Mukhtasar Khalil, cet ke-2, Beirut: Dar al-Madaru al-Islam, 2004.

Maliki, Khalil bin Ishaq al-Jundi al-. Al-Taudih fi Syarhi Mukhtashar al-Far'iyi li Ibni Hajib, Mesir: Dar Najibuih, 2008.

Mochtar, Rustam. Sinopsis Obsetetri, Jakarta: EGC, 1998.
Nurnazli. "Relevansi Penerapan Iddah di Era Teknologi Modern”, Ijtimaiyah, Vol. 10 No 1. Mei 2017

Rahman.Aspek Hukum Dan Medikolegal Abortus Povocatus Criminalis, http://Situs.Kerespro. Info,(23 April 2020).

Rangkuti, Layla Fadhilah dkk. "Abortus Imminens Di Rumah Sakit Umum Daerah Kota Padang Sidempuan", Jurnal Muara Sains, Teknologi Kedokteran Dan Ilmu Kesehatan, Vol. 3 No. 1, April 2019.

Romli, Dewani. "Aborsi Dalam Perspektif Hukum Positif Dan Hukum Islam (Suatu Kajian Komparatif)", Al-Adalah : Vol. X, No. 2 Juli 2011.

Sabiq, Sayyid.Fiqh Sunah, Beirut: Dar al-Fikr, 1983, Juz II.

Setyowati, Sri. Masalah Abortus Kriminalis di Indonesia dan Hubungannya Dengan Keluarga Berencana Ditinjau Dari Kitab UndangUndang Hukum Pidana, Jakarta: t.p., 2002.

Shan'ani, Muhammad ibn Ismail al-. Subul alSalâm, Beirut; Dar Ihya al-Turats al-'Arabi, 1379 H/ 1960 M, Cet. ke-4, Juz III

Susanti, Yuli. "Perlindungan Hukum Bagi Pelaku Tindak Pidana Aborsi (Abortus provocatus) Korban Perkosaan," FH.UNISBA: Jurnal Ilmu Hukum, 16, 2 (September 2010-Februari 2013).

Susilawati, Nilda. "Aborsi Dalam Tinjauan Hukum Islam”, Jurnal ilmiah Mizani, Vol. 2, no. 2 (2015).

Syukri Albani Nasution, Muhammad. Filsafat Hukum Islam, Jakarta: Rajawali Pers, 2014, cet. ke-2.

Undang-Undang Perkawinan, edisi lengkap, Bandung: Fokusmedia, 2005.

Warjiyati, Sri. "Aborsi Pada Masa Iddah Wanita Hamil Untuk Mempercepat Perkawinan Perspektif Hukum Islam”, Al-Ahwal, Vol.2, No. 1, 2019.

Warson, Ahmad. Kamus Al-Munawwir ArabIndonesia Terlengkap, Yogyakarta: Pustaka Progressif, 1997. 